Greer, C. (2003) 'Media Representations of Dangerousness', in Criminal Justice Matters, 51, Spring 2003: 45.

\title{
MEDIA REPRESENTATIONS OF DANGEROUSNESS
}

Media representations reflect a wide conceptualisation of 'dangerousness', which often bears little relation to professional definitions. This article considers the press representation of 'dangerous offenders' and wider notions of 'dangerousness' and 'risk', and discusses their construction in terms of both the determinants of newsworthiness and as a wider sociological phenomenon.

\section{Individual and Social Dangerousness}

Press representations of dangerousness tend to be constructed around two intertwining variants - individual and social. Individual dangerousness conjures images of recidivist, predatory offenders who encroach upon and violate the physical person. It is associated with - though not restricted to - those types of serious interpersonal crime which people imagine most vividly and are most afraid of. Social dangerousness relates to less serious, less immediately harmful activities; those crimes with which people may identify less viscerally, but which collectively are seen represent a threat to stability and social order. Images of car theft, vandalism, graffiti, underage drinking, and groups hanging around on street corners all summon notions of communities in decline, indifference to the social, and lack of respect for authority and law and order.

Though these categories are not mutually exclusive, their representation in the press can be quite distinct. Collectively, they serve as a conduit for widespread public fears and anxieties about rising levels of offending, personal safety and social decay, 
constructing a mediated world in which dangerousness is ubiquitous. The print media, of course, represent a diversity of values, interests and beliefs. Some newspapers are more tolerant of complexity than others and individual pieces - notably in the more liberal broadsheets - may at times question the effectiveness of relentlessly toughening up on criminal justice policy. More often, however, press representations lend support to a populist agenda which promotes individual control and containment over wider social reform.

\section{Newsworthiness and Social Decline}

The press interest in stories of serial rapists and predatory paedophiles is not difficult to understand. The criteria that determine 'newsworthiness' include human tragedy, immediacy (the here and now), novelty, dramatic events, and the involvement of deviant personalities. All of these elements are exemplified in narratives of pathological individuals perpetrating serious interpersonal offences against unsuspecting victims, especially when the attacker is still on the loose and could strike again. Though media representations routinely exaggerate the risks of falling victim to predatory interpersonal attacks, their newsworthiness derives in part from their novelty.

Wider, more diffuse notions of social dangerousness do not so obviously meet the criteria for newsworthiness, yet they routinely feature in press discourse. What makes these stories so reportable, in contrast to narratives of predatory violent offenders, is their lack of novelty. They are portrayed as widespread, as commonplace, as 'normal'. Problems of disorder and what is now termed anti-social behaviour, especially as associated with youth, have perennially been used as a visible index of social decline 
(Pearson, 1983). In contemporary society, however, high crime rates are an accepted fact of life, and fear, anxiety and insecurity have become defining characteristics of everyday existence. In this climate of uncertainty, narratives of general social decline and, in particular, the identification of particular groups and individuals to whom blame might be attached, maintain a firm grasp on the public imagination.

\section{Representation, Reaction and Reform}

The relationship between media representations, public opinion and criminal justice policy should not be oversimplified. It is beyond doubt, however, that media and public outcry can exert a significant influence over policy reform. High profile cases - the murder of Sarah Payne in 2000, the Dunblane school massacre in 1996, the murder of toddler James Bulger in 1993 - act as 'crystallising points for public concern' (Levi, 2003: 804). Sustained media attention, incorporating the attribution of blame and demands for punitive action, cannot be separated from policy developments which reflect an intensifying focus on law and order and 'responsibilisation', and the wider climate of social intolerance in which these developments find popular support.

In the wake of schoolgirl Sarah Payne's murder, the News of the World embarked on a campaign of 'naming and shaming' convicted child sex offenders in an effort to secure controlled public access to information about offenders released back into the community. The portrayal of all child sex offenders in this and other newspapers as equally dangerous legitimates and, at times, actively encourages their undifferentiated fear and loathing (Greer, 2003). Yet public hostility which frequently borders on the 
hysterical and the resultant exclusion of sex offenders from society does more to increase than decrease the risk of further offences (Wilson and Silverman, 2001).

The classification of Dangerous Severe Personality Disorder (DSPD) was established following outrage at the 1996 murder of Lin and Megan Russell by Michael Stone, who had been diagnosed with a personality disorder several years before. DSPD has no legal or medical status (Farnham and James, 2001), but those identified as suffering from this condition may face indeterminate incarceration, regardless of whether they have actually committed an offence or not.

The punitive rhetoric employed by both tabloids and broadsheets in reporting the James Bulger murder played its part in bringing about the abolition of doli incapax - the idea that children aged between ten and thirteen are incapable of committing a criminal offence (Newburn, 2003). Children as young as ten years old may now face the full force of the criminal law, and the severity of sentences available for young offenders has increased considerably.

It is the high profile cases that secure the biggest headlines and seize popular consciousness most forcefully, but in the aftermath of these cases notions of 'potential' dangerousness can be applied to whole groups. The mentally disordered can be portrayed as potential murderers, asylum seekers as potential terrorists, gun club members as potential spree killers. Those featuring in contemporary narratives of risk and dangerousness include rapists, murderers and child molesters, but also drug users, the mentally disordered and, most consistently and insidiously, young people. Once dangerousness is associated with a group rather than an individual, and the potential 
threat becomes widespread rather than isolated, the level of deviance required to make the headlines decreases markedly.

\section{The Context of Media Production}

Media images do not exist in a vacuum. They intersect with people's lived experiences in complex and varied ways. That the press overstate the prevalence of violent-sexualinterpersonal attacks does not mean that fear of crime is necessarily irrational. Some people are dangerous. Some communities are in decline. The risks of victimisation are not distributed evenly throughout society. For some people, the crime problem is every bit as acute as the popular tabloids would have us believe.

That said, the inflammatory potential of the press is beyond doubt, and selective and over-generalised narratives of crime and control do little to assuage people's concerns. The contours of crime news production undulate between images of the "enemy without' - whose representation in the press is based on the commission of serious predatory interpersonal offences, and the 'enemy within', whose very presence may be portrayed as a threat and whose acts need only border on the criminal to attract media scrutiny and public concern. As crime consciousness continues to grow, press representations become increasingly punitive, and society becomes more intolerant, the definition of dangerousness correspondingly expands. A fruitful area for more focused media debate may be the dangers posed by the sections of the press. 


\section{References}

Farnham, F. and James, D. (2001) 'Dangerousness and Dangerous Law' in Lancet, 358: 1926.

Greer, C. (2003) Sex Crime and the Media: Sex Offending and the Press in a Divided Society, Cullompton: Willan.

Levi, M. with Maguire, M. (2003) 'Violent Crime', in M. Maguire, R. Morgan and R.

Reiner (eds.) The Oxford Handbook of Criminology, third edition, Oxford: Oxford University Press.

Newburn, T. (2003) 'Young People, Crime and Youth Justice', in M. Maguire, R.

Morgan and R. Reiner (eds.) The Oxford Handbook of Criminology, third edition, Oxford: Oxford University Press.

Pearson, G. (1983) Hooligan: A History of Respectable Fears, London: Macmillan.

Wilson, D. and Silverman, J. (2002) Innocence Betrayed: Paedophilia, the Media and Society, Cambridge: Polity Press. 